$\begin{array}{lllllllllllllll}\text { A C T A } & \text { C H E M I C A } & \text { S C A N D I N A V I C A } & 12 & \text { (1 } 958) & 229-232\end{array}$

\title{
The Addition of Grignard Reagents to Alkylidenemalonic Esters
}

\author{
G U S T. - A D. H OLM B E R G
}

Institutet for organisk kemi, Abo Akademi, Abo, Finland

\begin{abstract}
Some aliphatic and aromatic Grignard reagents were allowed to react with othylidenemalonic and isobutylidenemalonic esters. In all cases the corresponding sec.-alkylmalonic esters were isolated. The main reaction thus seems to be 1,4-addition to the conjugated system.
\end{abstract}

For a planned investigation it was necessary to know the way in which $\mathrm{T}$ ethylidenemalonic ester ( $\mathrm{I}$ a) and $i$ sobutylidenemalonic ester ( $\mathrm{I}$ b) react with Grignard reagents. The literature does not give any information regarding these reactions. However, 1,4-addition has previously been observed in reactions between different Grignard compounds and isopropylidenemalonic ester (II).${ }^{1,2}$<smiles>[R]C=C(C(=O)OCC)C(=O)OCC</smiles><smiles>CCOC(=O)C(C(=O)OCC)=C(C)C</smiles>

$\mathrm{R}=$ (a) $\mathrm{CH}_{3}$

(b) $\mathrm{CH}\left(\mathrm{CH}_{3}\right)_{2}$

As the second methyl group at the $\beta$-carbon atom in this ester can hardly alter the course of the reaction with Grignard reagents it was expected that 1,4-addition would also occur with ethylidenemalonic and isobutylidenemalonic esters.

This prediction was confirmed when the esters were allowed to react with some aliphatic and aromatic Grignard reagents. The reaction products, sec.-alkylmalonic esters, were characterized by conversion into the corresponding barbituric acids. If the latter were not previously known compounds, the malonic esters were also saponified and the corresponding malonic acids iso-

Acta Chem. Scand. 12 (1958) No. 2 
Table 1. Reactions between Grignard reagents and ethyl alkylidenemalonates.

\begin{tabular}{|c|c|c|c|c|}
\hline \multicolumn{2}{|c|}{ Starting material } & \multicolumn{3}{|c|}{ Reaction product } \\
\hline $\begin{array}{l}\text { Grignard reagent } \\
\text { prepared from }\end{array}$ & $\begin{array}{l}\text { Ethyl } \\
\text { alkylidene- } \\
\text { malonate }\end{array}$ & Ethyl malonate & B.p. & $\begin{array}{l}\text { Yield } \\
\%\end{array}$ \\
\hline $\begin{array}{l}\text { Methyl iodide } \\
\text { Ethyl bromide } \\
n \text {-Propyl bromide } \\
\text { Bromobenzene } \\
\text { o-Bromotoluene } \\
\text { a-Bromonaphthalene } \\
\text { Methyl iodide } \\
\text { Bromobenzene } \\
o \text {-Bromotoluene }\end{array}$ & $\begin{array}{l}\text { Ethylidene- } \\
\text { Ethylidene- } \\
\text { Ethylidene- } \\
\text { Ethylidene- } \\
\text { Ethylidene- } \\
\text { Ethylidene- } \\
\text { Isobutylidene- } \\
\text { Isobutylidene- } \\
\text { Isobutylidene- }\end{array}$ & $\begin{array}{l}\text { Isopropyl- } \\
\text { 1-Methylpropyl- } \\
\text { 1-Methylbutyl- } \\
\text { 1-Phenylethyl- } \\
\text { 1-o-Tolylethyl- } \\
\text { 1-a-Naphthylethyl- } \\
\text { 1,2-Dimethylpropyl- } \\
\text { 1-Phenyl-2-methylpropyl- } \\
\text { 1-o-Tolyl-2-methylpropyl- }\end{array}$ & $\begin{array}{r}89-90^{\circ} 7 \mathrm{~mm} \\
107-108^{\circ} / 10 \mathrm{~mm} \\
117-118^{\circ} / 10 \mathrm{~mm} \\
155.5-157^{\circ} \% \mathrm{~mm} \\
166.5-168^{\circ} / 10 \mathrm{~mm} \\
213-214^{\circ} / 10 \mathrm{~mm} \\
120-121^{\circ} / 11 \mathrm{~mm} \\
167-169^{\circ} \% 9 \mathrm{~mm} \\
169-171 \% 9 \mathrm{~mm}\end{array}$ & $\begin{array}{l}82 \\
83 \\
76 \\
76 \\
68 \\
73 \\
81 \\
72 \\
72\end{array}$ \\
\hline
\end{tabular}

lated. These were then decarboxylated to the corresponding monocarboxylic acids. Both the malonic acids and the monocarboxylic acids were converted into their $p$-nitrobenzyl esters for identification.

The results are collected in Tables 1 and 2.

\section{EXPERIMENTAL}

The reactions between the Grignard reagents and the alkylidenemalonic esters were performed in a 250-ml flask fitted with a reflux condenser, a dropping funnel, and a stirrer with precision ground glass bearing. The upper ends of the condenser and the dropping

Table 2. Melting points of substances prepared from the synthesized malonic esters.

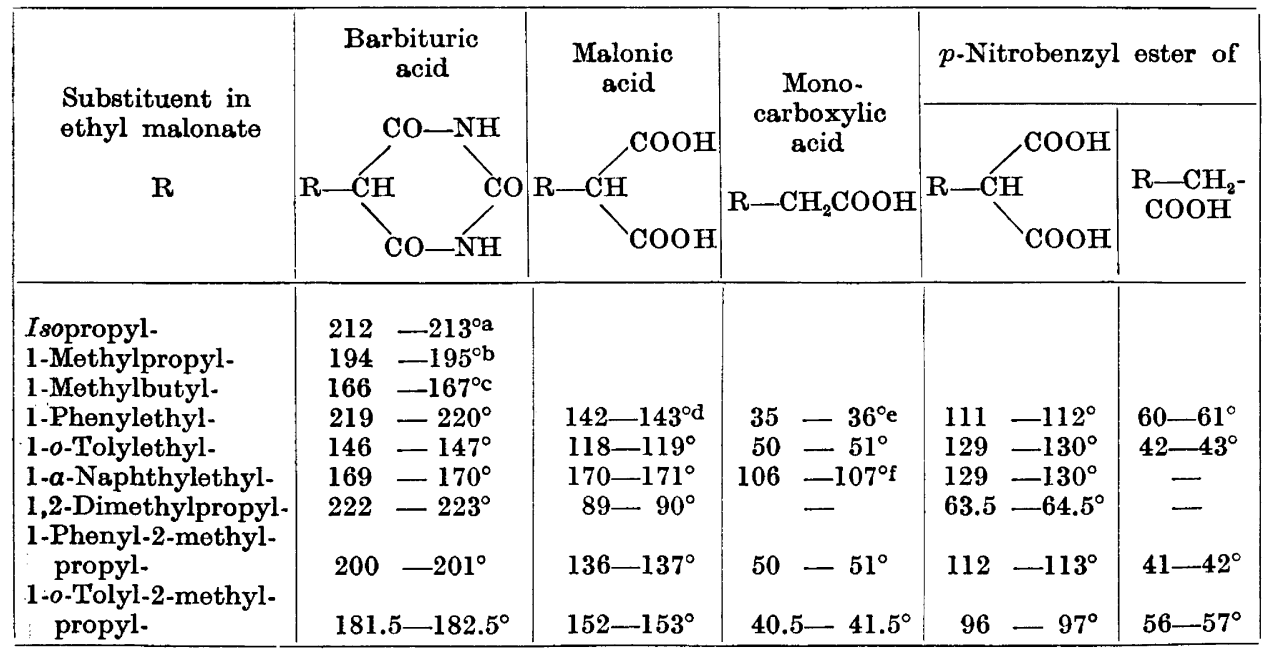

The literature gives a) $212-213^{\circ}$, b) $193-194^{\circ}$, c) $167-168^{\circ}$, d) $141-142^{\circ}$, e) $35-36^{\circ}$, f) $108-109^{\circ}$. 
Table 3. Analytical data for the new barbituric acids and $p$-nitrobenzyl esters of the prepared malonic and monocarboxylic acids.

\begin{tabular}{|c|c|c|c|c|c|c|}
\hline \multirow{3}{*}{$\mathrm{R}$} & \multirow{2}{*}{\multicolumn{2}{|c|}{$\underbrace{\substack{\text { Barbituric } \\
\text { acid } \\
\mathrm{CO}-\mathrm{NH}}}_{\mathrm{CO}-\mathrm{NH}}$}} & \multicolumn{4}{|c|}{$p$-Nitrobenzyl ester of } \\
\hline & & & \multicolumn{2}{|c|}{$\overbrace{\mathrm{COOH}}^{\mathrm{R}-\mathrm{CH}_{\mathrm{N}}^{\mathrm{COOH}}}$} & \multicolumn{2}{|c|}{$\begin{array}{c}\mathrm{R}-\mathrm{CH}_{2} \mathrm{COOH} \\
\mathrm{N}\end{array}$} \\
\hline & Found & Calc. & Found & Calc. & Found & Calc. \\
\hline 1-Phenylethyl- & 12.26 & 12.06 & 5.93 & 5.86 & 4.77 & 4.68 \\
\hline 1-o-Tolylethyl- & 11.52 & 11.38 & 5.81 & 5.69 & 4.55 & 4.47 \\
\hline 1- $a$-Naphthylethyl- & 10.08 & 9.92 & 5.50 & 5.30 & & \\
\hline 1,2-Dimethylpropyl. & 14.25 & 14.13 & 6.42 & 6.30 & & \\
\hline 1-Phenyl-2-methylpropyl- & 10.90 & 10.76 & 5.67 & 5.53 & 4.36 & 4.28 \\
\hline 1-o-Tolyl-2-methylpropyl- & 10.32 & 10.21 & 5.41 & 5.38 & 4.23 & 4.10 \\
\hline
\end{tabular}

funnel were fitted with calcium chloride tubes. A Grignard reagent was prepared from 0.15 mole of an alkyl or aryl halide, 0.15 mole $(3.60 \mathrm{~g})$ of magnesium turnings, and $70 \mathrm{ml}$ of dry ether. After the flask containing the reagent had been cooled in cold water, 0.10 mole of alkylidenemalonic ester was gradually added. After the addition, the stirring was continued for $20 \mathrm{~min}$. The solution was then poured into a mixture consisting of $70 \mathrm{ml}$ of conc. hydrochloric acid, $200 \mathrm{ml}$ of water and about $100 \mathrm{~g}$ of ice. After shaking, the organic phase was washed with water and with a dilute potassium carbonate solution. The acid water solution was extracted once with ether, and the ether layer was also washed with water and potassium carbonate before it was combined with the main portion. After drying with anhydrous sodium sulphate, the ether was evaporated and the residue distilled under reduced pressure. The yields and the boiling points are collected in Table 1.

The corresponding barbiturne acids were prepared in the following way. A sodium ethoxide solution was prepared from sodium $(0.55 \mathrm{~g})$ and absolute ethanol $(30 \mathrm{ml})$. Urea $(1.44 \mathrm{~g})$ and malonic ester $(0.02 \mathrm{~mole})$ were added. The mixture was boiled for six hours on a boiling water bath. If a precipitate had formed during this time, it was filtered, washed with a small quantity of absolute ethanol, and dissolved in water. The barbituric

Table 4. Analytical data for the new malonic and monocarboxylic acids.

\begin{tabular}{|l|c|c|c|c|c|c|c|c|}
\hline \multirow{2}{*}{$\mathrm{R}$} & \multicolumn{3}{|c|}{$\mathrm{R}-\mathrm{CH}(\mathrm{COOH})_{2}$} & \multicolumn{3}{c|}{$\mathrm{R}-\mathrm{CH}_{2} \mathrm{COOH}$} \\
\cline { 2 - 9 } & \multicolumn{2}{|c|}{ Found } & \multicolumn{2}{|c|}{ Calc. } & \multicolumn{2}{c|}{ Found } & \multicolumn{2}{c|}{ Calc. } \\
\cline { 2 - 9 } & $\mathrm{C}$ & $\mathrm{H}$ & $\mathrm{C}$ & $\mathrm{H}$ & $\mathrm{C}$ & $\mathrm{H}$ & $\mathrm{C}$ & $\mathrm{H}$ \\
\hline & & & & & & \\
1-o-Tolylethyl- & $\mathbf{6 4 . 7 5}$ & $\mathbf{6 . 4 2}$ & $\mathbf{6 4 . 8 5}$ & $\mathbf{6 . 3 5}$ & $\mathbf{7 4 . 2 5}$ & 8.01 & $\mathbf{7 4 . 1 3}$ & $\mathbf{7 . 9 2}$ \\
1-a-Naphthylethyl- & $\mathbf{6 9 . 6 2}$ & $\mathbf{5 . 5 6}$ & $\mathbf{6 9 . 7 5}$ & $\mathbf{5 . 4 2}$ & $\mathbf{7 8 . 5 9}$ & $\mathbf{6 . 7 1}$ & $\mathbf{7 8 . 4 8}$ & $\mathbf{6 . 5 9}$ \\
1,2-Dimethylpropyl- & $\mathbf{5 5 . 0 2}$ & $\mathbf{8 . 2 5}$ & $\mathbf{5 5 . 1 6}$ & $\mathbf{8 . 1 0}$ & & & & \\
1-Phenyl-2-methylpropyl- & $\mathbf{6 6 . 2 8}$ & $\mathbf{6 . 7 0}$ & $\mathbf{6 6 . 0 8}$ & $\mathbf{6 . 8 3}$ & $\mathbf{7 5 . 1 8}$ & $\mathbf{8 . 2 9}$ & $\mathbf{7 4 . 9 7}$ & 8.29 \\
1-o-Tolyl-2-methylpropyl- & $\mathbf{6 7 . 3 2}$ & 7.18 & $\mathbf{6 7 . 1 8}$ & $\mathbf{7 . 2 5}$ & $\mathbf{7 5 . 5 4}$ & $\mathbf{8 . 9 8}$ & $\mathbf{7 5 . 6 7}$ & $\mathbf{8 . 8 0}$ \\
\hline
\end{tabular}

Acta Chem. Scand. 12 (1958) No. 2 
acid was then precipitated by adding hydrochloric acid. If a precipitate had not formed in the barbituric acid condensation, the alcohol was distilled off under reduced pressure, the residue treated with water and ether, and the barbituric acid in the water phase precipitated by adding hydrochloric acid. The filtered acids were recrystallized from ethanol or aqueous ethanol. The melting points are collected in Table 2 and analytical data for the new barbituric acids in Table 3 .

The new malonic esters were converted into the corresponding acids in the following way. The ester $(5 \mathrm{~g})$ was boiled for $5 \mathrm{~h}$ with a solution of potassium hydroxide $(5 \mathrm{~g})$ in water $(5 \mathrm{ml})$ and ethanol $(50 \mathrm{ml})$. In some cases a precipitate of the corresponding potassium salt formed during this time or when the mixture was allowed to cool. The salt was filtered and dissolved in water. The corresponding malonic acid which precipitated on adding hydrochloric acid was filtered. A smaller amount of the same compour $d$ could be extracted from the filtrate with ether. A less pure sample was also obtained when the alcoholic filtrate was evaporated, the residue treated with water and ether, and the aqueous phase acidified with hydrochloric acid.

If a precipitate of potassium salt had not formed during the saponification, the alcohol was distilled off and the residue treated with water and ether. The malonic acid was then isolated from the aqueous phase as above.

When 1,2-dimethylpropylmalonic ester (prepared from methylmagnesium bromide and isobutylidenemalonic ester) was saponified, no precipitate was formed on adding hydrochloric acid to the aqueous solution. The solution was then extracted three times with ether. After drying and evaporation of the ether, the malonic acid was crystallized by treatment with ligroin and recrystallized from a mixture of benzene and ligroin.

The malonic acids were decarboxylated by heating in a oil bath at $180^{\circ}$ until evolution of carbon dioxide ceased. On treatment with ligroin the monocarboxylic acids crystallized. The latter were purified by recrystallization from the same solvent. The yields based on the decrease in weight during the decarboxylation were $97-99 \%$.

The melting points of the acids are collected in Table 2 and the analytical data for the new compounds in Table 4.

The $p$-nitrobenzyl esters were prepared according to Reid ${ }^{3}$.

\section{REFERENCES}

1. Wideqvist, S. Arkiv Kemi, Mineral. Geol. 23 B (1946) No. 4.

2. Prout, F. S., Huang, E. P. Y., Hartman, R. J. and Korpics, C. J. J. Am. Chem. Soc. 76 (1954) 1911.

3. Reid, E. E. J. Am. Chem. Soc. 39 (1917) 124.

Received October 25, 1957.

Acta Chem. Scand. 12 (1958) No. 2 